\title{
Exploration on the Training Mode of English Major Applied Talents
}

\author{
Wei Xu \\ Wuhan Donghu College, Wuhan, Hubei, 430212 \\ 5490500@qq.com
}

Keywords: English Major, Applied Talents, Exploration Method

\begin{abstract}
The weaknesses of the model are gradually exposed. In particular, graduates from local newly established universities have lower professional standards, weaker adaptive capacity, weaker innovation ability and less competition in the talent market than those from other institutions. In order to pursue development, applied technology university must be transformed to cultivate more excellent talents with applied technology to meet the market demand. The teaching of English major in this type of college is more challenging. It is particular important for English professionals to develop a professional training model --- professional orientation and curriculum settings, and develop students' learning and practical ability. This paper starts from the practical needs of the transformation of university applied technology, analyzes the meaning of personnel training mode in colleges and universities, analyzes the existing problems of English majors in this kind of university, and probes into the training mode of English majors in the new situation.
\end{abstract}

\section{Introduction}

In order to correctly understand and construct the training mode of English majors, we must first understand the conception and meaning of college personnel training mode. The Ministry of Education's connotation of "personnel training model" is described as follows: "The training model of personnel is the knowledge, ability, quality structure and the way of achieving this structure that the school constructs for the students. It fundamentally stipulates the talent characteristics and focuses Embodies the concept of education and education. "Many domestic educators and scholars have defined the concept of" personnel training mode ". The mode of personnel training is a medium used by both teaching parties. Through the teaching process and the corresponding curriculum, both inside and outside the school Under the common action, to achieve the goal of training personnel complex.

\section{Problems of English professional training mode}

The English majors' technical personnel training mode is a new-born thing in the reform of colleges and universities, which is different from the previous research type and the mode of personnel training in higher education. Many of the practical problems in the training and teaching of English majors in such institutions mainly focus on the following aspects: First, the objectives and concepts of English majors' training are different from those of cultivating the students. Some applied technology colleges and universities To become the first-class university in China as the goal of running a school, blind pursuit of the same talent training objectives with the first-class universities, ignoring the cultivation of skilled personnel should be adapted to the local social and economic development for this purpose. Second, English teaching and management organization, did not highlight the characteristics of applied technology-based theory of light practice, emphasizing the teacher's knowledge of traditional light teaching students ability to apply. Classroom teacher teaching theory not only occupy most of the class hours, and practical aspects of procrastination, internships in the form, resulting in students' ability to use English can not be exercised. Thirdly, the setting of the direction of English major and the setting of the curriculum model in the applied technology university can not meet the needs of social development and individual. For example, most English majors have a poor English foundation, while English majors 
and curriculums have the same contents and requirements as other well-known English majors in colleges and universities. Students are under great pressure to lead English majors Unprofessional, general education is not general, students are not interested in the curriculum set up. Finally, the survey of graduates from Liaodong College of Foreign Languages reveals that the translation of primary English teachers, training schools and economic and trade departments is the main employment direction of graduates. The choice of curriculum and difficulty in the modules of professional courses for English majors are different from the actual The market does not match the requirements. Based on this, in the face of the problems existing in teaching and training of English majors in applied technology university, the author explores how English majors can train skilled personnel to adapt to the market demand and develop the training mode of applied talents. For the transformation of colleges and universities and the reform of English majors Development is of great significance.

In the 1990s, the "Great Leap Forward" took place during the great development of English majors and the large-scale enlarging of enrollment. Some colleges and universities experienced the phenomenon of "students speak diplomas with the benefit of schools, leaders speak of performance, faculty speaks of scale, teachers lecture, And led to the "leaders think (doctoral, master's point), teachers want money, students want to idle" undesirable tendencies. The training model of English majors in science and engineering colleges is over-controlled by the market and the teaching model lacks necessary systematicness and stability. The result is often only talk about development, growth, not to mention the quality and effectiveness.

Some responsible persons do not have a clear understanding of the connotation of English majors, the relationship between disciplines and majors is not very clear, the planning of development is too large, and the echelon of talents is inefficient. There is a certain distance between the setting of professional courses and the requirements of "outline", the teaching plan is not complete, and the curriculum of curriculum and the content of completion are superficial.

Some leaders and teachers think that "compound type" is a simple summation of different disciplinary knowledge, overemphasizes the diversification of talent needs, and unilaterally pursues the cultivation of "applied type" personnel, forming a narrow and practical concept in guiding ideology. The result is that the emphasis on the instrumentalities of English is far more than the overall quality of training qualified personnel. The comprehensive training of English professionals has become a vocational training field.

Some teachers' teaching concepts and teaching methods are still not completely changed, professional standards, low level of teaching, unable to meet the new requirements. Due to the impact of the social environment, some teachers' professional ethics did not meet the requirements. They also run classes and classes with few courses and teaching materials, not to mention teaching and research. At the same time, students are not good at learning style and their learning interest is not strong. Some students indulge in computer games, online chatting, love and romance, martial arts novels and romance stories, fake time, abandoned school. In the model of "compound and applied" personnel training, a group of students did not reach the best of both worlds when they graduated, but rather lost both their positions in language and literature, and did not master the relevant professional knowledge. Specific performance is not fluent in spoken language and accuracy, poor grammar skills, writing is low, there is no literary meaning, but no cultural awareness. Some students lack ability, graduation thesis copy, buy, translate. These so-called "compound type, application type" talent but instead of professional professionals, not prominent "two unlike."

After large-scale enlarging enrollment, many colleges and universities appear a series of contradictions such as the decline of student quality, imperfect school facilities, the lack of building of teaching staff, lack of humanity in teaching methods and teaching management, lack of teaching materials and even library books, There have even been problems such as the personnel training mode can not keep up with social development, the curriculum and teaching contents do not meet the needs of the society, the students' knowledge structure, ability and quality are not suitable for jobs, and so on. 


\section{Practice and Reforming Strategies of English Professional Talents Training Modes}

The above problems have arisen. Therefore, we can not deny the "compound and applied" personnel training mode of English majors in science and engineering institutes, and moreover, we should not neglect them and neglect them. This status quo has shown that it is very difficult for our English majors to achieve the training objectives stipulated in the National Syllabus. Therefore, the practice of cultivating English majors in English should be continued, and the training mode of "complex and applied" English talents should be deepened and further deepened. If we want to effectively solve the current various contradictions, overcome difficulties, make the best use of the available resources and train truly qualified English professionals for the country, we must conduct in-depth studies and come up with countermeasures.

It is necessary to carry forward the emphasis of practical and strong application of science and engineering colleges, but also to see the short history of English majors in colleges of science and technology, starting late enough to effectively do discipline planning, keep in mind that the construction of English majors in science and engineering must be subject-oriented construction Leader (Qin Xiubai, 2006: 4). Therefore, in disciplinary construction, we must first select and determine the direction of disciplines, and establish the directions of economy, trade, science and technology according to the existing conditions and practical experience of universities of science and technology. Only when the disciplines are mature and the foundation is solid, will they apply and develop new disciplinary directions, give full play to their traditional advantages, strive to innovate, and find new growth points (such as directly establishing a translation major). Definitely not one-sided scale, seek quantity, blind development. At the same time, we should step up the construction of subject echelon, cultivate academic leaders and academic leaders, and build an academic team with professional title structure, educational structure and age structure. Bearing in mind that the development of foreign language professionals lies in the building of a contingent of qualified personnel. On this basis, we should strengthen academic research, teaching and research, expand exchange and cooperation, carry out academic exchange activities, build a platform for teachers, and continuously improve teachers' academic standards and scientific research ability, and change their educational concepts and teaching methods.

In terms of professional setup, we adhere to the concept of "thick foundation and wide caliber", emphasize English as the fundamental, take the relevant knowledge of economy and trade as the direction (module), cultivate the professionals needed by the society, satisfy the development of science and technology, Cultural Progress and Change Needs for Innovative Talents. In terms of curriculum, English professional skills courses, English professional knowledge courses, relevant professional knowledge courses such as economics, trade, science and technology as well as content-rich elective courses are set according to the teaching stage, and the course arrangement and proportion structure are continuously optimized.

In the teaching process, students are the center, social needs are the direction, advanced teachers are used to arm teachers, make full use of teaching resources and use high-tech means such as internet and multimedia to organize teaching. On the basis of completing routine teaching tasks, we should actively carry out the second classroom activities to cultivate students' interest in learning and stimulate their potentialities. At the same time, do a good job teaching materials, with particular attention to the cultivation of students' cultural awareness. In practice, we should carry forward the tradition of science and technology institutions, reorientation, scientific demonstration and evaluation of oral English intensive training, oral internship, professional internships and graduation internships and other sectors, strengthen practical teaching, and effectively strengthen the writing guidance of the students' thesis . Change the test means, according to the teaching situation and the actual needs and the characteristics of the curriculum, using a variety of means to assess and test the students' learning and practice. At the same time, we should pay attention to the personal factors of foreign language learners, such as intelligence, linguistic abilities, cognitive styles, personality traits, learning strategies, motivation, age and gender (Liu Runqing 2000: 185). Strengthen teaching management and change the single teaching mode of "self-reliance" in the past, and adopt the method of "please come in and go global"; train young and middle-aged backbone teachers; invite 
experts and scholars to give lectures; lecture by external visiting professors; Supervision, pay close attention to the construction of morality and style of study, improve teaching quality.

The application of technical undergraduate education should adhere to the combination of theory and practice, pay attention to practicality, "practical" is a notable feature of applied undergraduate course. German University of Applied Sciences practice a long time, focusing on technical content, skills, a special 20-week internship semester. According to the requirements of the Ministry of Education, many colleges and universities in our country have formulated the university's practical teaching plan. Taking the English Department of Liaodong University as an example, two weeks of practice time are set for each academic year, with the participation of teachers and students. However, the practical teaching effect is not Ideal, practical content and forms of activity to a variety of competitions and theatrical performances, the basic teaching class derivatives. Some domestic institutions of internship semester is mainly arranged (or asked) students to business perception, into the social workout. Of course, the form of internship practice can be similar or even professional with no professional social exercise, the best way is to school-enterprise cooperation. English major can consider working with foreign trade companies or joint ventures to develop students' practical ability.

\section{Conclusion}

The mode of personnel training in applied technology colleges and universities must be reformed in accordance with the requirements of diversified talents in the society and the market, and the cultivation of "application" and "ability" should be emphasized according to the characteristics and needs of the industry. Under the background of transformation of applied technology colleges and universities, the construction of English professional training mode should be based on the research of the position of applied technology-oriented university and the meaning of talent training mode. All departments of the government should provide policy and legal support and all sectors of society should provide Through the research methods such as questionnaire and so on, we can understand the demand for English majors in the region, construct the training mode of English majors suitable for their own colleges and universities, and reflect the local characteristics of training mode personalise. The implementation of personnel training to be meticulous and effective, English professional training model to develop a reasonable talent training objectives and professional courses, to determine the teaching content and methods and personnel training evaluation mechanism, pay attention to the talent's ability of knowledge and quality structure relationship, the relationship between basic theoretical knowledge and professional knowledge, the relationship between general skills and professional skills, reflecting the diversity and openness of English professionals to mobilize the initiative and enthusiasm for student learning, improve students' practical ability to achieve suitable goal of developing skilled personnel for economic development.

\section{References}

[1] Liu Chunyan. Training Objectives and Interdisciplinary Curriculum Design of Applied English Majors in Colleges and Universities [J] .Journal of Foreign Languages. 2010 (04)

[2] Zhou Ying, Fan Yi. Connotation and level orientation of English majors in compound talents training [J] .Journal of Foreign Languages. 2010 (04)

[3] Liu Fagong. China's business English from scratch [J]. Foreign Language. 2009 (06)

[4] Ping Hong exploration of business English undergraduate professional training mode [J]. Chinese foreign language. 2009 (04)

[5] Fan Xiaoyun. Study on the Cultivation of Compound Talents in College Business English [J]. Market Modernization. 2007 (36)

[6] Zhao Junfeng. Business English curriculum and teaching status quo survey [J]. Chinese Foreign Languages. 2006 (05) 